\title{
Mud Marine: The Rise and Fall of Mangalore Tiles
}

Ian M. Cook

If you climb atop a high-rise apartment in Mangaluru, India, and look down you will see a trickle of red-tiled roofs among the trees. Caressed by rivers to the north and south, the coastal city's red-tiled houses were once a characteristic visual marker of the region. And, if you are accompanied on your trip into the clouds by one of the city's elderly residents, then they might bemoan the loss of a distinctive cityscape. The concrete blocks that grow in number and size each year do not look much different from those in Bengaluru, Mumbai or Chennai.

Nostalgic locals might further point out that the red tiles made from clay gathered at the riverbanks bear the name of the city itself: Mangalore tiles. And, moreover, Mangalore tiles once had an international reputation that spoke to the bountiful offerings of land and the ordering promise of industrial modernization. But that was some time ago. Now, next to no one wants to live in a 'tiled house'.

I want to invite you down from atop the high-rise and into the mud of Tulu Nadu, the region of which Mangaluru is the largest city. An examination of the colonial and post-colonial buildings reveals the walls that serve as real barriers of exclusion, but also the in-between spatial structures of the built form: framed in-between material and representational planes, and in-between local 
and colonial cultural formations (Scriver and Prakash 2007). The specific histories produce a built environment that, while in a modern (global) city, also exhibit cultural logics that fall outside planetary urbanization (Jazeel 2018). The layers of overlapping, crumbling, moss-ridden tiles speak to the overlapping, crumbling and nature-reclaiming temporal and spatial frameworks of coloniality, post-coloniality and indigeneity. It is possible to see the straight lines of a 'civilizing' empire; neoliberalism's desire to produce global representations of sameness; land's material, economic and poetic instability; ghostly hauntings from the past and future; insecure masculine militaristic language; and the scattered remains left by the transmogrifications of empires.

\section{Missionaries, Materials and Modernization}

In Tulu Nadu, $\mathrm{V}$-shaped roof tiles have been produced for centuries, utilizing the clay found on the banks of the Netravathi and Gurupura rivers, but the region's tiles rose to prominence after the production process was industrialized by the Basel Evangelical Missionary Society, which arrived in India in 1834, not long after the British captured Mangalore in 1799. The protestant missionaries needed both employment for their converts and funds for their activities and thus set up a printing press and a weaving shop, among other industries. If you peruse the mission archives at the Karnataka Theological College in Mangaluru, you will find numerous mentions of technical innovation including the introduction of the fly-shuttle into weaving, the (possible) invention of khaki cloth dye and the use of hand, bullock and stream power in tile factories. The first such factory was opened in Jeppu, south of the city proper, in 1865, and it was so successful that the mission opened two more factories in the region (Prabhu 1999), and other industrialists, such as British coffee trader Morgan, soon followed suit. 
With the outbreak of World War I in 1914, the Swiss Germans were increasingly unwelcome. Holdings were transferred to a specially set up Commonwealth Trust Limited in 1920 (Raghaviah 1990), which, following independence in 1947, became an Indian company in the 1970s. After closing between 2006 and 2013 , it is once again making tiles; however, as the manager of the factory told me, production is now at a much lower rate due to a longstanding manual labour shortage, dwindling supplies of clay and cheap competition from elsewhere. Many of the tile factories in and around this city have either closed or operate on a significantly smaller scale.

While the land around the Jeppu factory no longer offers much clay, it has acquired increased value owing to a real estate boom, accentuated in this part of the city by the promise of a riverside ring road. As a way of paying off debts, the Commonwealth Trust mortgaged its land. However, in the process it discovered it did not have full rights over all twelve acres in Jeppu. Two acres were held through the mulageni system, a locally unique form of perpetual renting.

This is where a local Swiss-British developer stepped in. Upon learning that the Commonwealth Trust could not sell the land, he tracked down the papers, found the family of the original landlord (or mulagar), purchased the land outright and started building a high-rise complex, the Aquamarine. Mangaluru has many such luxury high-rises, some populated, some left empty by investors or 'black money' launderers. It is not clear yet which of these the Aquamarine will become. The developer's father used to be a manager at a close-by factory owned by Peirce \& Leslie, a colonial-era company. Peirce \& Leslie bought the property from the Morgans, the above-mentioned British coffee traders and tile makers, who left India around the 1920s. The old Morgan property was sold by Peirce \& Leslie to a subsidiary of 
the famous coffee chain Café Coffee Day, which was founded by the son-in-law of the former chief minister of the state of Karnataka, who studied at a college in the city.

These different historical threads are woven into the built environment, entangled with one another. In the following photo essay, I explore the colonial visual traces of missionaries, traders and luxury through depictions of materials, walls and buildings all gathered from within a few hundred square metres in Jeppu, Mangaluru. These are arranged across three groups of images: the Basel Mission works and Morgan property as depicted in photographs found in the Basel Mission Archives; the Commonwealth Tile Works and Morgan properties today; and, the upcoming luxury high-rise. The photographs are intertwined with excerpts from interviews with the developer, a night watchman and a housing agent; selections from academic texts that theoretically frame the essay relating to lines, land and representation; and literary passages from a colonial-era novel about a British tile maker in Mangalore, a contemporary Tulu poem about a family house, and a news site's puff piece on the Aquamarine. It is my aim to mix excerpts and photographs in a way that resonates with the entanglements found within Mangaluru's built environment; to highlight how both building materials and material photographic affordances coalesce around particular colour palettes and thus produce certain affective-aesthetic qualities; and to compare how vertical, diagonal and sloping lines can frame both the landscape and its photographic representations in ways that reveal the layered continuities in the material, abstract and creative production of in-betweenness during the British Raj, through the first decades of independence, and into the unabashedly hyper-capitalist contemporary period. 
... the straight line has emerged as a virtual icon of modernity, an index of the triumph of rational, purposeful design over the vicissitudes of the natural world. The relentlessly dichotomizing dialectic of modern thought has...associated straightness with mind as against matter ... with civilization as against primitiveness, and - on the most general level with culture as against nature.

Ingold (2007: 153).

At night I am accompanied by a guard until 11. Until 11 the guards will whistle, after 11 we'll sleep ... There's ghosts here. Three dead bodies were found. I was afraid. No one is prepared to stay alone ... we saw some of the dead bodies in this river. They were near the railway track.

Stani, Night Watchman at the Commonwealth Tile Factory.

Ross took the steep path up the side of ... [the hill] There the immensity and the stillness were frightening; the moon was macabre; the constellations were all wrong; they stood on their heads, they were contorted into sinister malformations. But there was red now in the east. He walked to the edge, and seating himself on a laterite block looked down on ... [the river]. At first he looked into a well of darkness; then the river began to shine, first silver, then grey, then steely blue. Then suddenly crowding from all sides the details of the landscape began to gather; they rushed into their places like an army forming on parade. The east reddened, reddened, burst into flame as the 
sun suddenly swung himself over the distant crests of ... [the hill]. The sinister constellations vanished, the macabre moon became a ghost; the sun came striding into his own.

'That's my sun rising,' thought Ross. 'That's me'.

Brown (1936: 55-56).

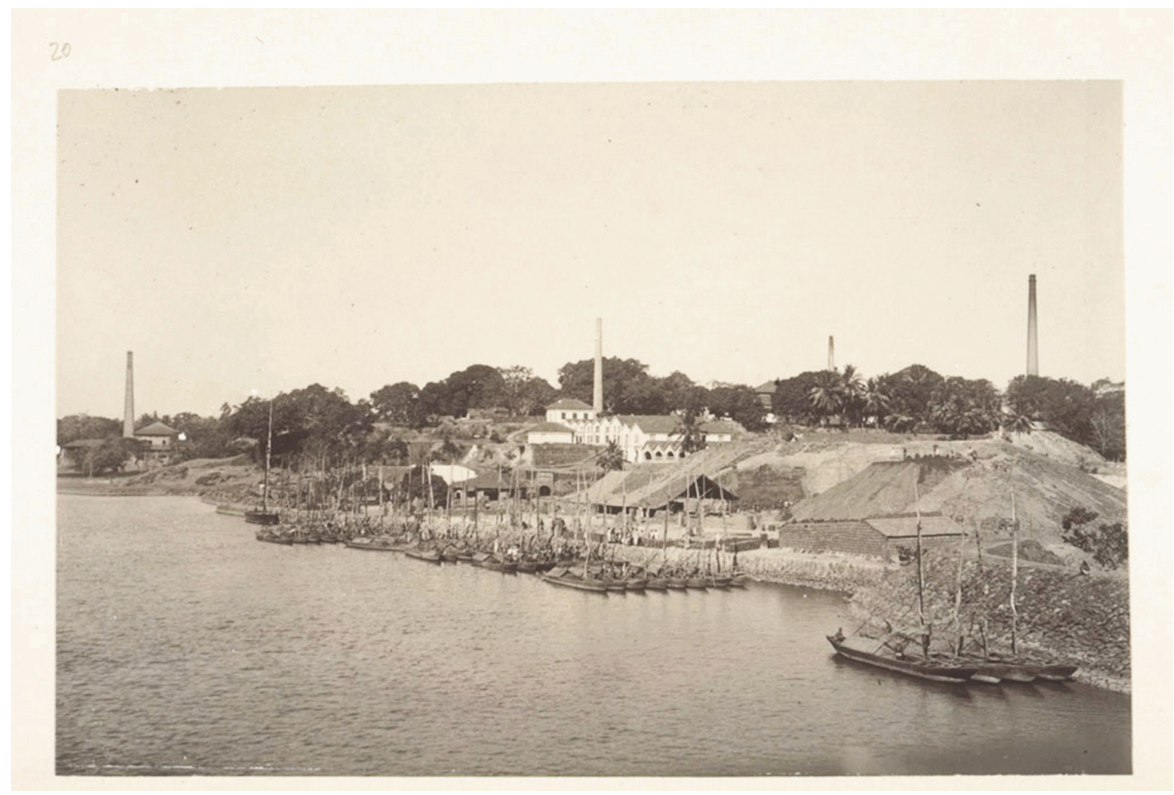

Figure 1: From the muddy banks of the Netravathi river a tile factory stands. Unknown, Jeppu Tile Factory. 1 January 1901. BMA QC-30.007.0020. BMArchives. 


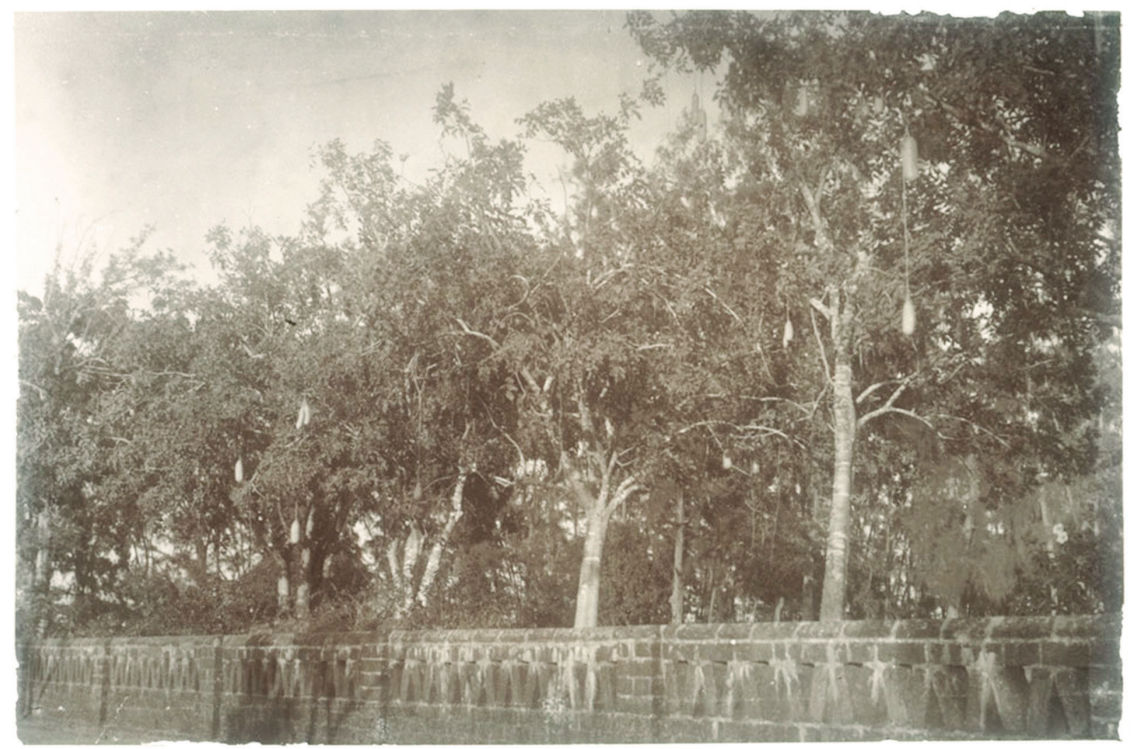

Figure 2: The Garden of Mr Morgan, Jeppoo. 1 January 1901. QC-30.018.0028.

BMArchives.

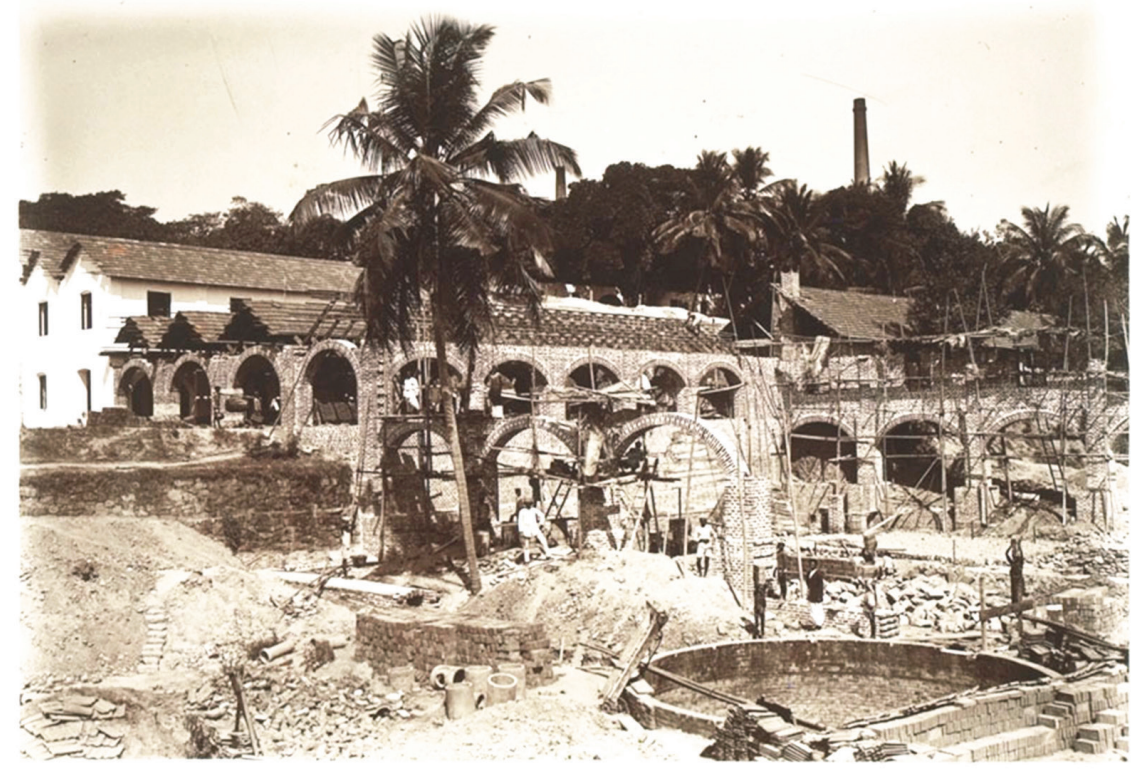

Figure 3: Mangalore Tile-Works at New Jeppu under Construction. Unknown. QU30.016.0073. BMArchives. 
Land is ... a variable category which can feed into, and be used by, different actors ... It moves, shifts and transforms in size as well as in other biophysical qualities whether intended for dwellings, agriculture or countless other purposes.

Kadfak and Oskarsson (2017: 41).

There used to be lots of clay here, now the tile manufactures have to go far - also its low quality. When we were young we used to get nice clay to play with, to mould in to things, you know?

Developer of the Aquamarine.

It is leaking! The roof of Tulu-Mother's ancestral house! The quarrelling folks of the house do not care for the house The main-hall, the ground and all Are muddied badly... and hopelessly!

When everyone is haggling over partition

Who has time to fix the leaking roof with a piece of spathe? No one cares for covering the holes with layers of dry grass! The front-yard is all covered with moss - stand firmly you cannot!

But lady-guest from across the Seven Seas had strong, storied house!

And a golden cot too...!

The Tulu rivers were rich and bountiful

But children of our own Mother were tenants and serfs...

Alike (2017). 


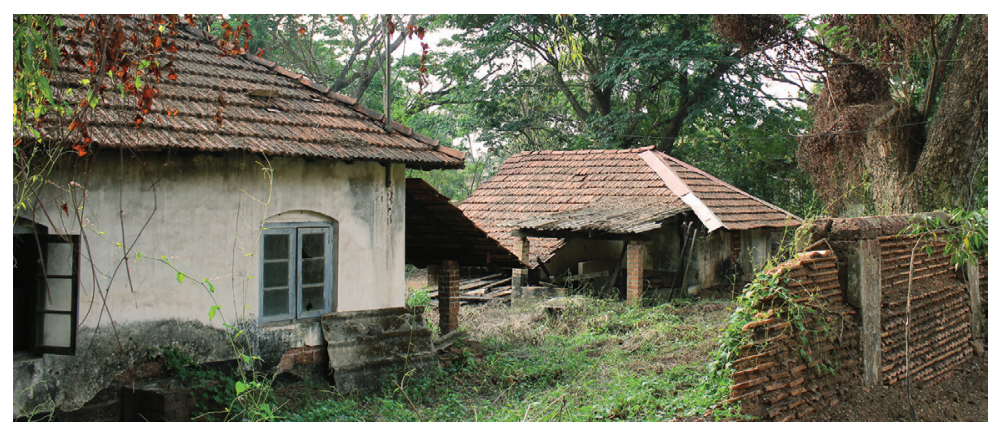

Figure 4: The garden of Mr Morgan.

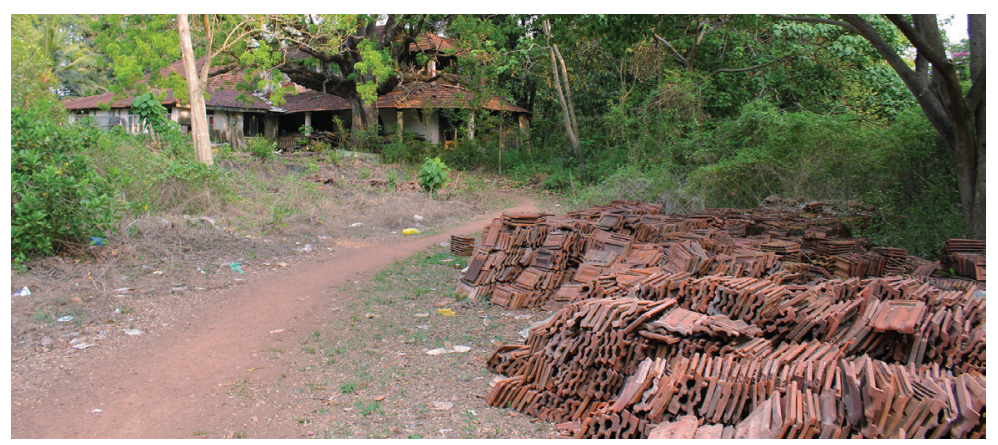

Figure 5: A pile of tiles by one of the 'Morgan Bungalows'.

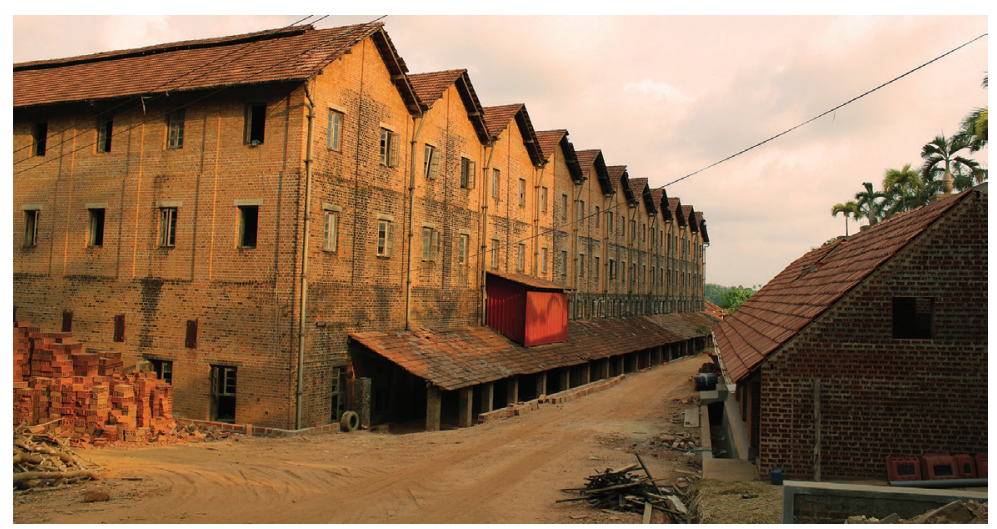

Figure 6: The sun setting on the Commonwealth Trust's Jeppu tile works. 
For capitalism to work as a structure of representation, that is, as a way of appearing to distribute phenomena in terms of a distinction between a real world and its meaning, it must have an identity. There must be some characteristic that is the essence of capitalism, some element of sameness, so that as it develops and expands one can recognize its occurrence through different material and temporal manifestations and hold together its story.

Mitchell (1988: 245).

15 years back ours was an underdeveloped market. In South Canara, in Mangalore, it used to be $80 \%$ tiled houses, now it's 80\% RCC [Reinforced Cement Concrete].

\section{Ramesh, Housing Agent.}

It is the only apartment complex where you have a breath-taking view of both the Nethravati River and Arabian Sea from your window. It is a sight to behold and can melt away many a hearts by just looking out of your bedroom window. And seeing the river frolic as it joins the sea ...

'Aquamarine' is geographically perfect in its location. Set right next to Mangalore Club, it is away from the hustle and bustle of city life, bringing peace and serenity into the residents' evenings yet not so far away as to make life inconvenient.

Daijiworld Media Network (2018). 


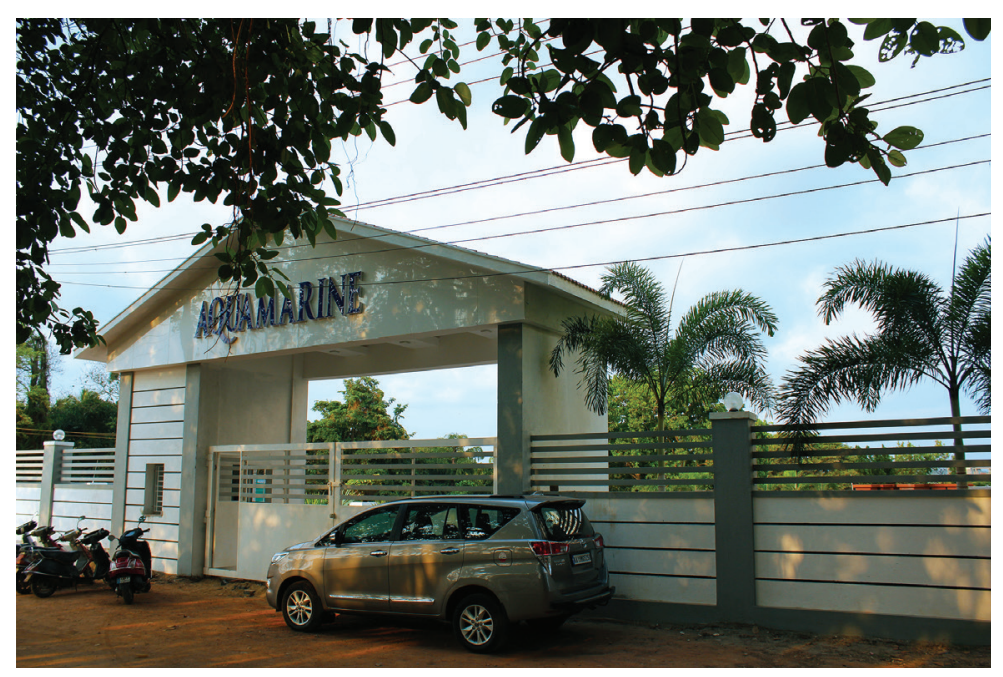

Figure 7: Gateway to a resort-like experience.

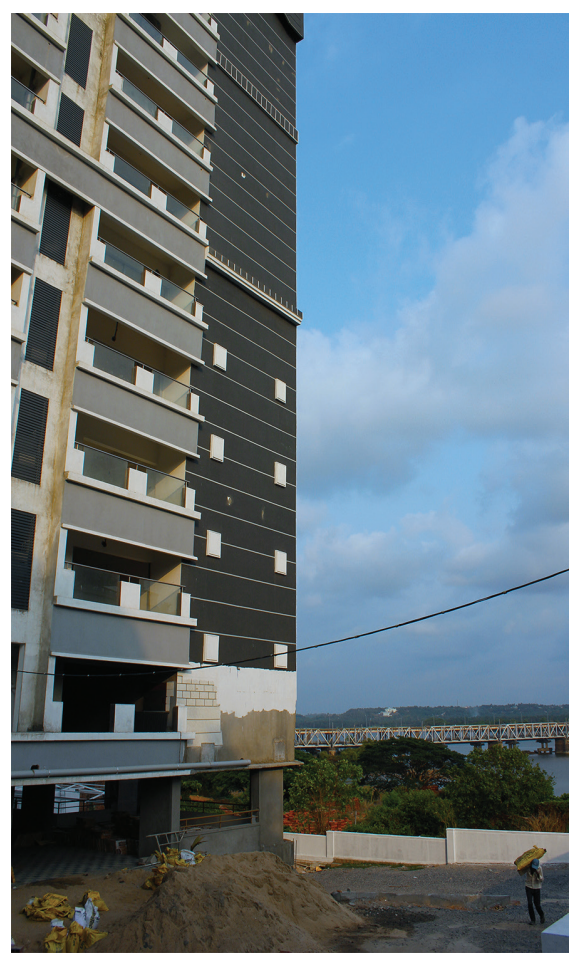

Figure 8:

Constructing a representation. 


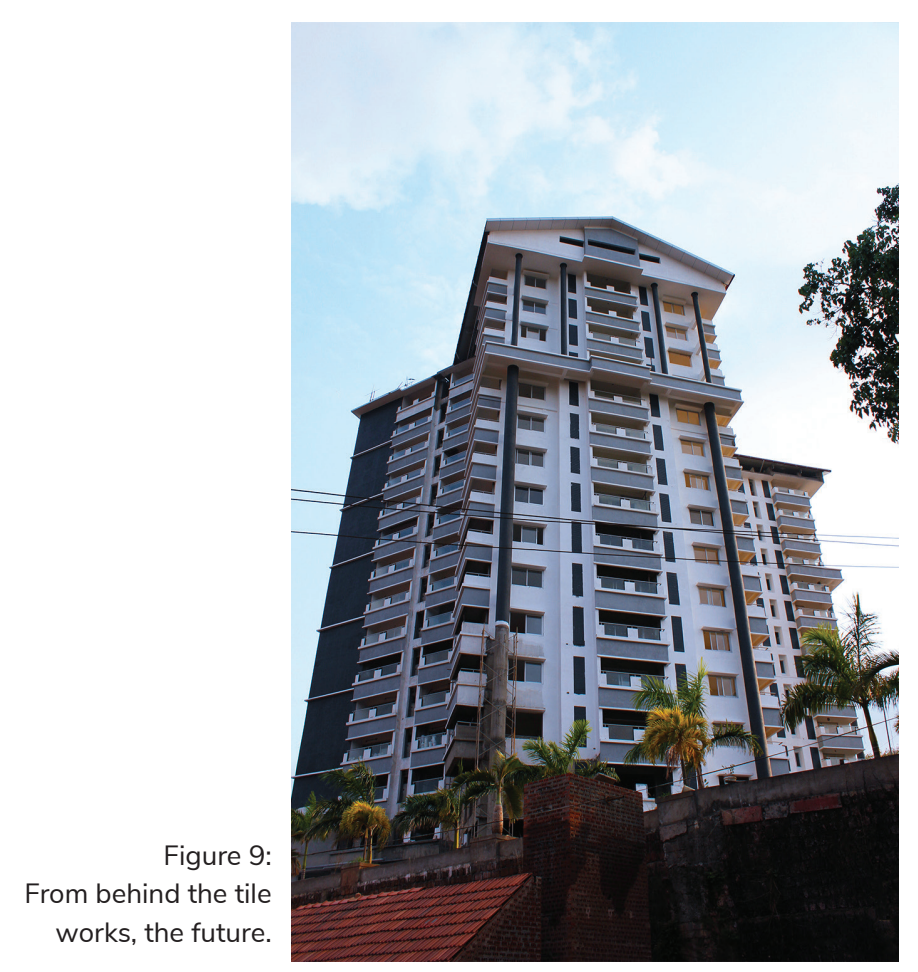

IAN M. COOK is an anthropologist with a regional focus on south India, based at Central European University in Budapest. He can be reached at CookI@spp.ceu.edu andianmickcook@gmail.com. 


\section{References}

Alike, Chennappa P. 2017. 'Our Tulu Mother's House'. In Ladle in a Golden Bowl: Translation of Tulu Poems, edited by Surendra B. Rao and Chinnappa K. Gowda. Arehole Pratishtana, Bejai, Mangalore: Aakrithi Aashaya Publications.

Brown, Charles Hilton. 1936. Torteval. London: Butler and Tanner. Daijiworld Media Network. 2018. “'Aquamarine”, City's First Apartment with Estuary Views'. Daijiworld.com, 2 February. http:// www.daijiworld.com/news/newsDisplay.aspx?newsID=493730.

Ingold, Tim. 2007. Lines: A Brief History. London and New York: Routledge.

Kadfak, Alin, and Patrik Oskarsson. 2017. 'The Shifting Sands of Land Governance in Peri-Urban Mangaluru, India: Fluctuating Land as an "Informality Machine" Reinforcing Rapid Coastal Transformations'. Contemporary South Asia 25:4, 399-414: 1-16. https://doi. org/10.1080/09584935.2017.1387097.

Jazeel, Tariq. 2018. 'Urban Theory with an Outside'. Environment and Planning D: Society and Space 36, no. 3 (1 June): 405-419. https://doi.org/10.1177/0263775817707968.

Mitchell, Timothy. 1988. Colonising Egypt. Cambridge and New York: Cambridge University Press.

Prabhu, M. Mukunda, ed. 1999. 'Tile Industry'. In POLI: A Commemorative Volume for Canara 200, 112-116. Mangalore: Deputy Commissioner, District Administration, Dakshina Kannada District.

Raghaviah, Jaiprakash. 1990. Basel Mission Industries in Malabar and South Canara, 1834-1914: A Study of Its Social and Economic Impact. New Delhi: Gyan Books.

Scriver, Peter, and Vikramaditya Prakash. 2007. Colonial Modernities: Building, Dwelling and Architecture in British India and Ceylon. London: Routledge. 


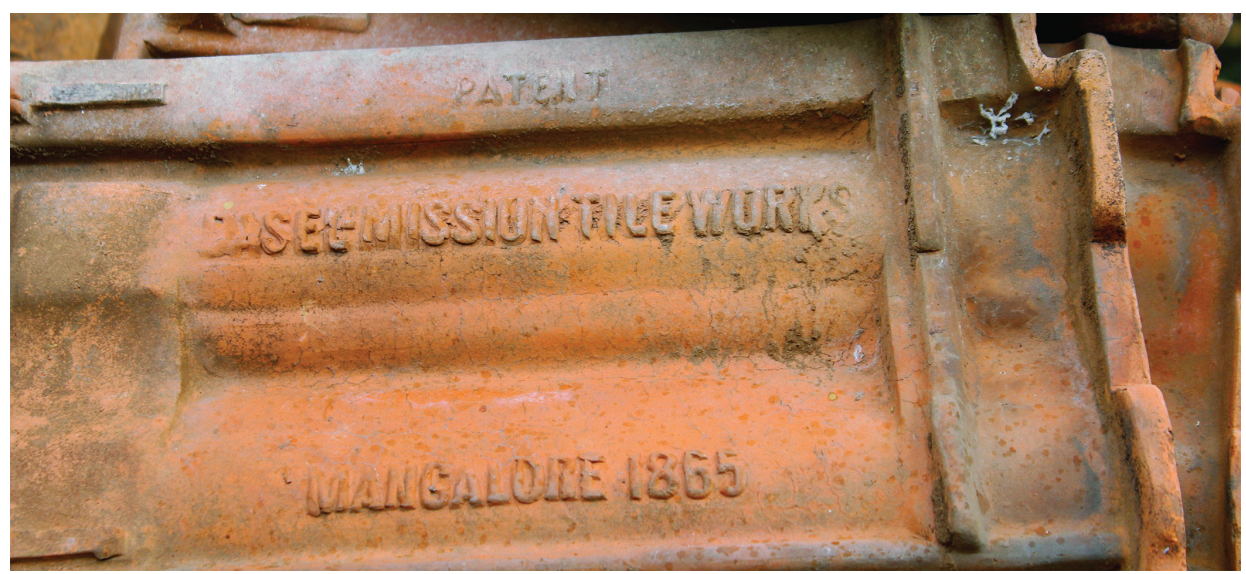

Figure 10: Mangalore tiles. 